\title{
TREND OF PUBLIC MASS TRANSPORT INDICATORS - AS A TOOL OF TRANSPORT MANAGEMENT AND DEVELOPMENT OF REGIONS
}

Quantification of customer requirements is necessary for all managers that continually monitor changing transport market environment and the quantification also introduces a fundamental tool that allows evaluations of current situation. On the basic assess of reached results in last periods of time the quantification also contributes to create a quality proposal of future lead to entrepreneurship in transport. The article deals with problems of possible application of appropriate methods of application that allow to reach the best quantification of next customer requirements in transport, also contribute to realization of strategic objectives and development and improve decision making concerning next trends in region.

Keywords: regional management, mass public transport (MPT), prediction, methods, public mass transport indicators

\section{Introduction}

Regional development is more dependent on and influenced by articles and activities of managers in several regions for their ability to learn and innovate in conditions of permanently realized dynamical changes in regional macroenvironment and also in microenvironment. With respect to these facts, greater resolution sets to action and projects the character of future trend monitoring indicators of development regional planning that will note the influence of changed external environment, new globalization tendencies, integration and increased pressure of competition.

The aim of regional management to create operational conditions and development of territorial independently operating system - region, impacted and developed in competitive environment, advocacy of development concepts, generation of new project ideas and also contribution to creation of conditions for successful position of responsible region.

Also passenger transport influences the positive development. It contributes to accommodate the everyday requirements of customers to transport and contributes to physical achievement of basic transport objective: free movement of people.

\section{Importance of regional management}

Spatial distribution of the Slovak territory was changed successively from time perspective, by management, level of understanding, tool facility and also by influence of changed external conditions. Nowadays we can assess the trend of various parts of territory in particular by dividing to regions $\sim$ Bratislava, West Slovakia, Central Slovakia and East Slovakia, but every region has reached different results with respect to particularities of several regions.

Regional management can be defined as a regional planning tool, global attitude to existing and new planned tasks, new philosophy of planning, new conception of leadership and realization of intentions.

Regional management is able to:

- mobilize internal and external potential,

- provide current information for regional development and focus on trend to future, possibilities of new technologies and innovative applications,

- use of applications of specific plans, provisions and projects by professional project management,

- sales and coordination of available regional resources from personnel skills and organizational point of view.

Regional marketing presents the key aspect of specific techniques and procedures allowing a management application in real conditions of the region. Regional marketing also includes the procedures oriented to creation, preservation or change of attitudes or behaviour to the region. The regional marketing offers methods and tools to ensure the development given by the region and acquirement of its prosperity. It defines products and development perspectives and introduces the conformity of region supply together with market requirements and evaluation and optimal using of its

\footnotetext{
* Jana Dicova ${ }^{1}$, Jan Ondrus ${ }^{2}$

${ }^{1}$ Faculty of Management Science and Informatics, University of Zilina, Slovakia, E-mail: Jana.Dicova@fri.uniza.sk

${ }^{2}$ Faculty of Operation and Economics of Transport and Communications, University of Zilina, Slovakia
} 
resources and complete potential. The regional marketing leads to satisfaction of regional requirements together with public interests.

\section{Mass Public Transport in Regions and Possibilities of Prediction}

Mass public passenger transport presents an important social and economic component of environment in its impact. It has the character of a population service focusing on tasks consisting of accommodating its everyday requirements for transport (travel to work, schools, offices, health centres, etc.). This task is - in conditions of the SR - dominant in participation of passenger bus and railway transport and has unforgettable (non-representational) position in suburban and railway transport and urban passenger transport within transport services of urban agglomerations and cities. [6]

Mass public transport is an important functional component of a town and region and we can divide it to [5]:

a) mass public transport that ensures the transport serviceability of a region:

- regular (periodic) bus transport :

- long-distance bus transport,

- suburban bus transport,

- railway public transport:

- realized on state-owned railways,

- realized on regional railways.

b) mass public transport that ensures transport serviceability of a town:

- urban bus transport,

- trolley transport,

- tram transport,

- subway.

Transport requirements of population present a significant factor of life style and the function of public transport is providing such transport connection so that it arises the requirement to be satisfied in the utmost degree. And at the same time the transportation should be carried out the most efficiently due to the nature of the region. [3]
Quantification of customers' requirements in transport process can by transport indicators (number of passengers and transport performance). The trend can be to define as progression of indicators that are changed with respect to time function, dependence on parameters and represents trend tendencies of movement.

The Slovak Republic can be divided to following regions:

= West Slovakia (Trnava, Trencin, Nitra districts),

= Central Slovakia (Banska Bystrica, Zilina districts),

$=$ East Slovakia (Kosice, Presov districts),

$=$ Bratislava district.

Trend of number of passengers in several regions of the Slovak Republic is a process for period $2001-2008$, sees Table 1. From long-term perspective trend in number of passengers we can observe that in each region there is a decrease every year. The greatest decrease of number of passengers was in Central Slovakia. There was a decrease in number of passengers in one year from 193,117 million of passengers to 112,720 million of passengers, which represents substantial decrease by $41.6 \%$ between years the 2001 and 2008. Conversely, the lowest decrease in the number of passengers was in Bratislava region, concretely $25.5 \%$ from 22,743 million of passengers in the year 2001 to 16,934 million of passengers in year 2008. The average decrease of number of passengers in all the regions during the period $2001-2008$ is by $35.5 \%$ : from 566,445

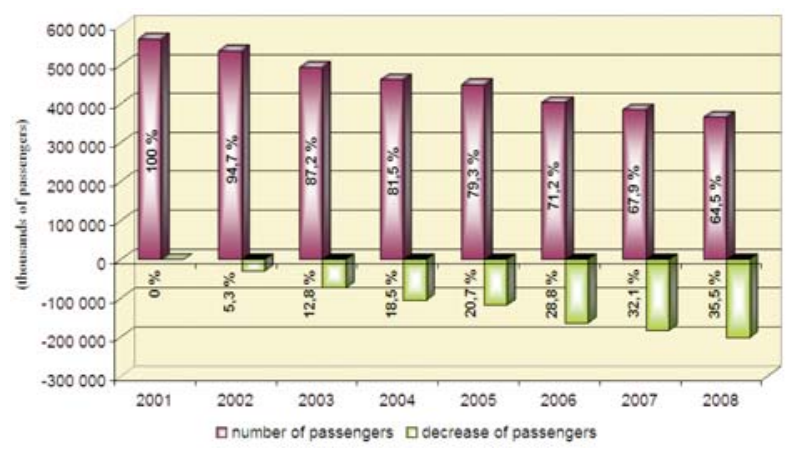

Fig. 1 Trend in Number of Passengers in Enterprises which are Specialized in Road Transport in Regions of Slovak Republic

Number of Passengers in the Enterprises which are Specialized in Road Transport (thousands of passengers)

Table 1

\begin{tabular}{|l|c|c|c|c|c|c|c|c|}
\hline \multirow{2}{*}{\multicolumn{1}{|c}{ Region }} & \multicolumn{7}{|c|}{ Number of passengers (thousands of passengers) } \\
\cline { 2 - 10 } & $\mathbf{2 0 0 1}$ & $\mathbf{2 0 0 2}$ & $\mathbf{2 0 0 3}$ & $\mathbf{2 0 0 4}$ & $\mathbf{2 0 0 5}$ & $\mathbf{2 0 0 6}$ & $\mathbf{2 0 0 7}$ & $\mathbf{2 0 0 8}$ \\
\hline Bratislava district & 22743 & 22549 & 20220 & 19014 & 18229 & 17658 & 17094 & 16934 \\
\hline West Slovakia & 228726 & 210574 & 187298 & 177984 & 184004 & 160058 & 155547 & 152328 \\
\hline Central Slovakia & 193117 & 184941 & 174878 & 161323 & 149186 & 130528 & 122413 & 112720 \\
\hline East Slovakia & 121859 & 118549 & 111310 & 103451 & 98037 & 95026 & 89583 & 83537 \\
\hline Total & $\mathbf{5 6 6 \mathbf { 4 4 5 }}$ & $\mathbf{5 3 6} \mathbf{6 1 3}$ & $\mathbf{4 9 3} \mathbf{7 0 6}$ & $\mathbf{4 6 1 7 7 2}$ & $\mathbf{4 4 9} \mathbf{4 5 6}$ & $\mathbf{4 0 3 2 7 0}$ & $\mathbf{3 8 4} \mathbf{6 3 7}$ & $\mathbf{3 6 5 5 1 9}$ \\
\hline
\end{tabular}

Source: The Statistical Office of the SR 
million of passengers in 2001 to 365,519 million of passengers in 2008 (Fig. 1).

To ensure the transport serviceability in regions, systems participate with different capacity of the means of transport and with different change of passengers. It is necessary to monitor also the realized transport performance in millions of passengers per kilometre except the number of passengers. There is a comparison of transport performance and its trend during several years of monitoring time in the table 2. The greatest decrease of transport performance was in Central Slovakia. Decrease of transport performance per year from 2362 millions of passengerkilometres to 1701 millions of passengerkilometres presents substantial decrease by $28 \%$ between years the 2001 and 2008. The lowest decrease of transport performance was in East Slovakia: only 16.2 \%, from 2288 million of passengerkilometres to 1917 million of passengerkilometres.

Figure 2 shows the processed trend of transport performance in several regions of Slovak Republic in monitored time during the years 2001 - 2008. While number of passenger in enterprises specialized in road transport in several regions of Slovak republic decreases, the transport performance in monitored time has also moderately increasing tendency (for example years 2002, 2004, 2006). In 2008, the transport performance in several regions of Slovak Republic was at a level of $78.1 \%$ of transport performance realized in 2001 .

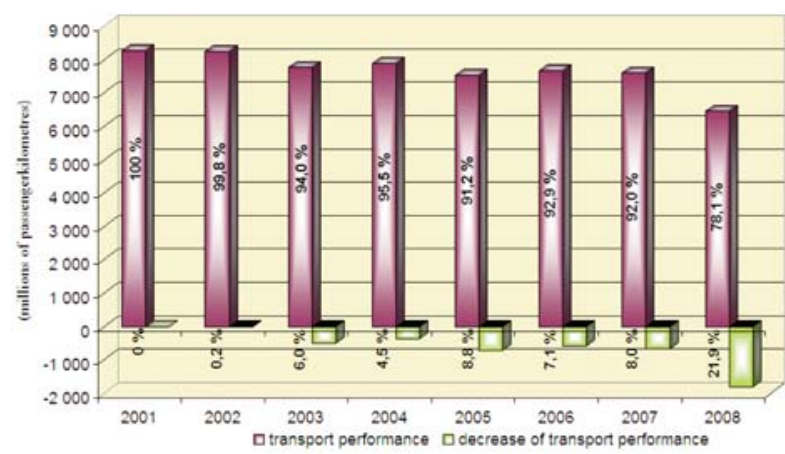

Fig. 2 Trend of Transport Performance in Enterprise Specialized in Road Transport in Regions of Slovak Republic
Succession of steps that allow determining the forecast of transport indicators trend to future is represented at Fig. 3. Input information for choosing the appropriate model of trend and prediction introduces quantified customer requirements of transport process (indicators of performances MPT) take into consideration spatial distribution of Slovakian territory and time aspect (time period: years 2001-2008).

The corect identification of input information creates the basis for modelling, which is a tool of systemic analysis of complicated problem solving where it can include also the determination of development of investigating indicators prediction. Model choice is influenced by time series analysis of input information on basis of decomposition. The main reason of decomposition is a revelation of relations and trend tendencies; depurated from seasonality, the forecast is better purposed. The main condition is to represent every single value of time series that can be represented as a summation or product of its components by single models of time variable.

View of Selected Prognostic Methods

Table 3

\begin{tabular}{|l|c|l|}
\hline \multicolumn{1}{|c|}{ Methods } & Form & \multicolumn{1}{c|}{ Characteristic } \\
\hline $\begin{array}{l}\text { Exponential } \\
\text { smoothing } \\
\text { (Brown's } \\
\text { model) }\end{array}$ & $T_{t-k}=A_{0 t}-A_{1 t} \cdot k$ & $\begin{array}{l}\text { = } \\
\text { based on increase of observed } \\
\text { value towards initial situation (con- } \\
\text { dition), represents trend relation, } \\
\text { typical is increase growth rate of } \\
\text { models parameters, }\end{array}$ \\
\hline $\begin{array}{l}\text { Holt's } \\
\text { exponential } \\
\text { smoothing }\end{array}$ & $T_{t}=A_{0 t}+A_{1 t} \cdot t$ & $\begin{array}{l}\text { = using exponential smoothing, } \\
\text { appropriate to application if time } \\
\text { series have evidently linear trend } \\
\text { and exponential smoothing takes } \\
\text { distorted value, }\end{array}$ \\
\hline $\begin{array}{l}\text { Quadratic } \\
\text { trends }\end{array}$ & $\begin{array}{c}T_{t}=A_{0}+A_{1} \cdot t+ \\
+A_{2} \cdot t^{2}\end{array}$ & $\begin{array}{l}\text { not suitable method to application } \\
\text { of prognosis with remote time, } \\
\text { application in case if trend has } \\
\text { parabola shape. }\end{array}$ \\
\hline
\end{tabular}

Application of selected methods represents a choice of appropriate trend function for given time series on the basis of realized

Number of Transport Performance in the Enterprises Specialized in Road Transport (Millions of Passengerkilometres)

\begin{tabular}{|l|c|c|c|c|c|c|c|c|}
\hline \multirow{2}{*}{ Region } & \multicolumn{9}{|c|}{ Transport performance (millions of passengerkilometres) } \\
\cline { 2 - 10 } & $\mathbf{2 0 0 1}$ & $\mathbf{2 0 0 2}$ & $\mathbf{2 0 0 3}$ & $\mathbf{2 0 0 4}$ & $\mathbf{2 0 0 5}$ & $\mathbf{2 0 0 6}$ & $\mathbf{2 0 0 7}$ & $\mathbf{2 0 0 8}$ \\
\hline Bratislava district & 566 & 820 & 483 & 511 & 469 & 479 & 478 & 449 \\
\hline West Slovakia & 3037 & 3101 & 2888 & 2938 & 2886 & 3009 & 3076 & 2379 \\
\hline Central Slovakia & 2362 & 2125 & 2178 & 2022 & 2065 & 2050 & 2145 & 1701 \\
\hline East Slovakia & 2288 & 2190 & 2208 & 2411 & 2105 & 2127 & 1897 & 1917 \\
\hline Total & $\mathbf{8 2 5 3}$ & $\mathbf{8 2 3 6}$ & $\mathbf{7 7 5 7}$ & $\mathbf{7 ~ 8 8 2}$ & $\mathbf{7 5 2 5}$ & $\mathbf{7 6 6 5}$ & $\mathbf{7 5 9 6}$ & $\mathbf{6 4 4 6}$ \\
\hline
\end{tabular}

Source: The Statistical Office of SR 


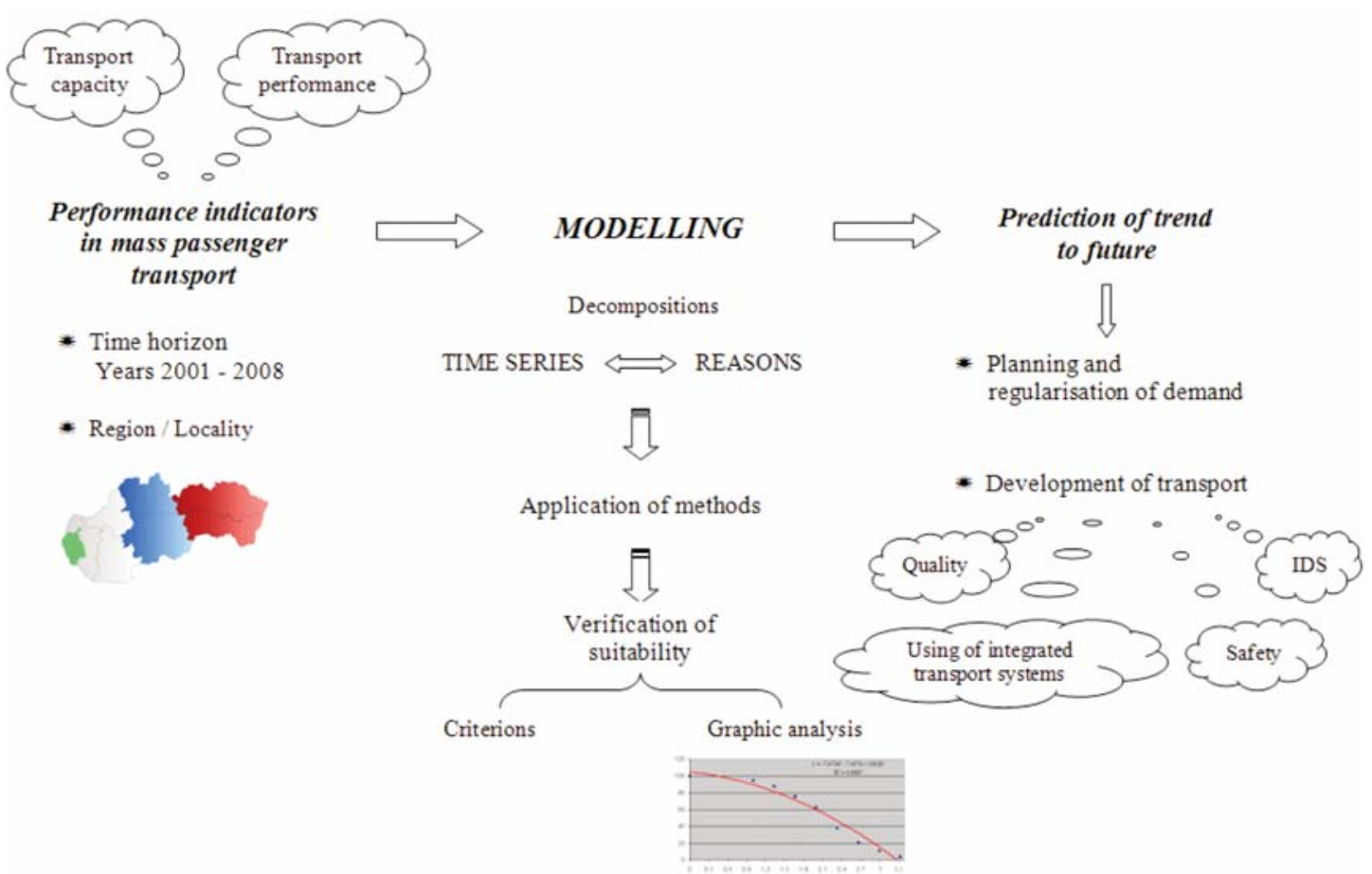

Fig. 3 Succession of Steps for Determination of Trend Performance MPT

decomposition and estimated attributes of development with respect to examined problems. From value time trend will be estimated model parameters. In case that we initiate presumption parameters, the complete condition of importance can be used to determination of forecast.

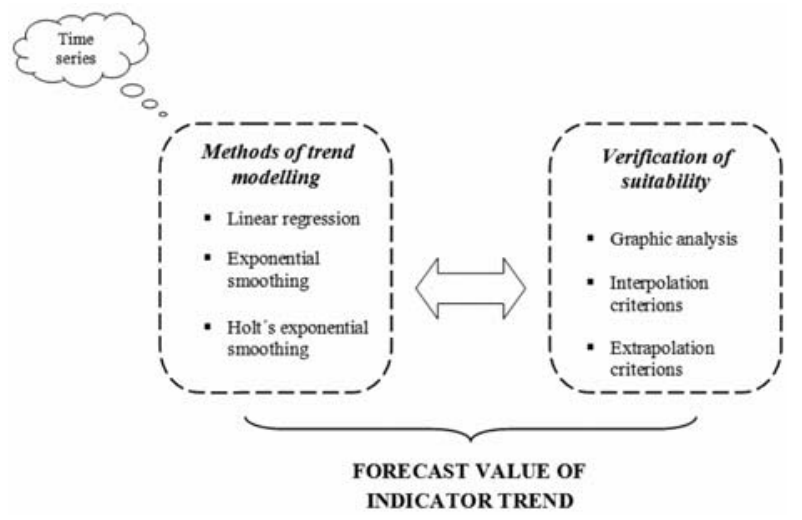

Fig. 4 Succession of Steps for the Forecast of the Indicator Trend

Verification of appropriateness of applied methods is realized on basis of adjudication of selected criteria because of the reason of measure precision; smoothing finding or average value residues characteristics (variance of real trend value $y_{t}$ and smoothing $\sim$ estimated trend value $\hat{y}_{t}$ ) introduces value RMSE.

$$
R M S E=\frac{1}{N} \sum_{i=1}^{N}\left(y_{t}-\hat{y}_{t}\right)^{2}
$$

Consecutively after evaluation of reached results quantities, value of future trend investigating indicators follows the period of the year 2009.

Indicators of MPT of Bratislava Region at the Period of Years 2001-2009

\begin{tabular}{|c|c|c|c|c|}
\hline \multirow[b]{2}{*}{ Year } & \multicolumn{2}{|c|}{ Value of MPT indicator } & \multicolumn{2}{|c|}{ Predictions of MPT indicator } \\
\hline & $\begin{array}{l}\text { Number of pas- } \\
\text { sengers } \\
\text { (thousands of } \\
\text { passengers) }\end{array}$ & $\begin{array}{l}\text { Transport per- } \\
\text { formance } \\
\text { (millions of } \\
\text { passengerkilo- } \\
\text { metres) }\end{array}$ & $\begin{array}{l}\text { Number of } \\
\text { passengers - } \\
\text { by methods } \\
\text { exponential } \\
\text { smoothing }\end{array}$ & $\begin{array}{c}\text { Transport per- } \\
\text { formance - by } \\
\text { methods Holt's } \\
\text { exponential } \\
\text { smoothing }\end{array}$ \\
\hline 2001 & 22743 & 566 & 22571.1 & - \\
\hline 2002 & 22549 & 820 & 21547.7 & - \\
\hline 2003 & 20220 & 483 & 20570.6 & 508.87 \\
\hline 2004 & 19014 & 511 & 19637.8 & 491.09 \\
\hline 2005 & 18229 & 469 & 18747.4 & 494.41 \\
\hline 2006 & 17658 & 479 & 17897.3 & 475.61 \\
\hline 2007 & 17094 & 478 & 17085.8 & 468.11 \\
\hline 2008 & 16934 & 449 & 16311.0 & 465.13 \\
\hline 2009 & - & - & 15571.4 & 449.12 \\
\hline
\end{tabular}

* Note. Prediction was evaluated from time series from years 2003 2008 
In monitored period of time 2001-2008, there was by indicator transport performance one extreme value by indicator of transport performance (in 2002 there was an increase of $44.86 \%$, but in next years this difference wasn't repeated any more). This value was a negatively influenced and misrepresented quantification of followed indicators forecast of MPT - transport performance, with respect to application smoothing method. So it was necessary to regulate the following time series and time series were applied for the forecast of years 2003-2008. To initiate the regulated time period, the service methods were used on basis of graphic analysis adjudication Holt s exponential smoothing and methods of linear trend and methods exponential smoothing. After the application of time series, the verification of appropriateness single methods by selected criterions followed. As the most appropriate methods that describe in the best way the trend of time series methods, Holt's e exponential smoothing has been evaluated because by determined criterions, it has reached the lowest value of RMSE (value was $22,8061)$ and all model parameters were important. Other applied methods had no important model parameters and so can't recommend the application these methods (methods of linear trend and exponential smoothing). Number of passengers by using method exponential smoothing reached the best results and the forecast values for the year 2009 were quantities of 15571,4 thousand of passengers.

Indicators of MPT of West Slovakia Region at the

Table 5 Period of Years 2001-2009

\begin{tabular}{|c|c|c|c|c|}
\hline \multirow[b]{2}{*}{ Year } & \multicolumn{2}{|c|}{ Value of MPT indicator } & \multicolumn{2}{|c|}{ Predictions of MPT indicator } \\
\hline & $\begin{array}{l}\text { Number of pas- } \\
\text { sengers } \\
\text { (thousands of } \\
\text { passengers) }\end{array}$ & $\begin{array}{l}\text { Transport per- } \\
\text { formance } \\
\text { (millions of } \\
\text { passengerkilo- } \\
\text { metres) }\end{array}$ & $\begin{array}{l}\text { Number of } \\
\text { passengers - } \\
\text { by methods } \\
\text { exponential } \\
\text { smoothing }\end{array}$ & $\begin{array}{c}\text { Transport } \\
\text { performance - } \\
\text { by methods } \\
\text { exponential } \\
\text { smoothing }\end{array}$ \\
\hline 2001 & 228726 & 3037 & 220291 & 2910.31 \\
\hline 2002 & 210574 & 3101 & 208061 & 2940.86 \\
\hline 2003 & 187298 & 2888 & 196509 & 2979.49 \\
\hline 2004 & 177984 & 2938 & 185599 & 2957.42 \\
\hline 2005 & 184004 & 2886 & 175295 & 2952.74 \\
\hline 2006 & 160058 & 3009 & 165563 & 2936.64 \\
\hline 2007 & 155547 & 3076 & 156371 & 2954.09 \\
\hline 2008 & 152328 & 2379 & 147689 & 2983.50 \\
\hline 2009 & - & - & 139489 & 2837.69 \\
\hline
\end{tabular}

Values of transport performance time series reached relatively periodic trend in monitored period of years 2001-2008, the only exception created the year 2008, when there was a rapid decrease by $20,70 \%$ to value 1701 millions of passengerkilometres. For this trend, selected methods were applied - methods of exponential smoothing, Holt's e exponential smoothing and Brown's linear exponential smoothing. On the basis of criterion of the lowest value acquirement, RMSE can be considered as the most appropriate in the method of exponential smoothing (value RMSE is 250.83). But it is necessary to point out that prediction value to year 2009 will also be influenced by the rapid change of value transport per- formance which started the year before (in 2008) and its next trend. The best way how the recommended application was considered was by application recommended method. For the trend of indicator number of passengers, the best method described was exponential smoothing, Holt's e exponential smoothing, but the better measure of smoothing precision $(\mathrm{RMSE}=7622.89)$ was reached by application method exponential smoothing.

Indicators of MPT of Central Slovakia Region at the

Table 6 Period of Years 2001-2009

\begin{tabular}{|c|c|c|c|c|}
\hline \multirow[b]{2}{*}{ Year } & \multicolumn{2}{|c|}{ Value of MPT indicator } & \multicolumn{2}{|c|}{ Predictions of MPT indicator } \\
\hline & $\begin{array}{l}\text { Number of pas- } \\
\text { sengers } \\
\text { (thousands of } \\
\text { passengers) }\end{array}$ & $\begin{array}{l}\text { Transport per- } \\
\text { formance } \\
\text { (millions of } \\
\text { passengerkilo- } \\
\text { metres) }\end{array}$ & $\begin{array}{l}\text { Number of pas- } \\
\text { sengers - by } \\
\text { methods Holt's } \\
\text { exponential } \\
\text { smoothing }\end{array}$ & $\begin{array}{l}\text { Transport per- } \\
\text { formance - by } \\
\text { methods Holt's } \\
\text { exponential } \\
\text { smoothing }\end{array}$ \\
\hline 2001 & 193117 & 2362 & 194569 & 2366.55 \\
\hline 2002 & 184941 & 2125 & 181833 & 2323.30 \\
\hline 2003 & 174878 & 2178 & 170893 & 2164.41 \\
\hline 2004 & 161323 & 2022 & 160675 & 2100.44 \\
\hline 2005 & 149186 & 2065 & 149465 & 1983.98 \\
\hline 2006 & 130528 & 2050 & 137929 & 1949.94 \\
\hline 2007 & 122413 & 2145 & 123305 & 1939.78 \\
\hline 2008 & 112720 & 1701 & 110655 & 2007.53 \\
\hline 2009 & - & - & 99175.7 & 1803.55 \\
\hline
\end{tabular}

Trend of transport performance can describe in the best way by methods of exponential smoothing and Holt's exponential smoothing with respect to progress of time series of input information from monitoring time. Considering the suitability model criterion determined as the most appropriate methods Holt's exponential smoothing and the followed indicator has decreased, value 99175.7 thousand of passengers by RMSE $=3829.37$. On the basis of initial adjudication of graphic representation of time series trend of transport performance, these trend selected follow methods were determined - exponential smoothing and Holt's exponential smoothing. Both these methods can be applied with respect to importance of model parameter, but by taking into consideration of criterion RMSE. The best method is Holt's exponential smoothing (RMSE has value 181.82 and method exponential smoothing has reached the value RMSE $=189.31$ ).

Parabolic trend of number of passengers had pointed out appropriateness using of method quadratic trends but in following period, there is a forecast of decrease of indicators to value 79369.5 thousands of passengers. Time series of transport performance value in monitored time was evaluated with respect to trends by methods exponential smoothing, Holt's exponential smoothing and Brown's linear exponential smoothing. Method of exponential smoothing after application forecasted too high value of smoothing constant and for that reason its application wasn't good. Method Brown's linear exponential smoothing has reached convenient results but RMSE has higher value (162.61) in comparison with method Holt's exponential smoothing that achieved value RMSE $=150.04$ after appli- 
Indicators of MPT of East Slovakia Region at the Period of Years 2001-2009

\begin{tabular}{|c|c|c|c|c|}
\hline \multirow[b]{2}{*}{ Year } & \multicolumn{2}{|c|}{ Value of MPT indicator } & \multicolumn{2}{|c|}{ Predictions of MPT indicator } \\
\hline & $\begin{array}{l}\text { Number of pas- } \\
\text { sengers } \\
\text { (thousands of } \\
\text { passengers) }\end{array}$ & $\begin{array}{l}\text { Transport per- } \\
\text { formance } \\
\text { (millions of } \\
\text { passengerkilo- } \\
\text { metres) }\end{array}$ & $\begin{array}{c}\text { Number of } \\
\text { passengers - } \\
\text { by methods } \\
\text { exponential } \\
\text { smoothing }\end{array}$ & $\begin{array}{l}\text { Transport per- } \\
\text { formance - by } \\
\text { methods Holt's } \\
\text { exponential } \\
\text { smoothing }\end{array}$ \\
\hline 2001 & 121859 & 2288 & 122953 & 2272.36 \\
\hline 2002 & 118549 & 2190 & 116694 & 2227.03 \\
\hline 2003 & 111310 & 2208 & 110667 & 2164.24 \\
\hline 2004 & 103451 & 2411 & 104872 & 2127.14 \\
\hline 2005 & 98037 & 2105 & 99308,1 & 2179.29 \\
\hline 2006 & 95026 & 2127 & 93976.0 & 2127.61 \\
\hline 2007 & 89583 & 1897 & 88875,6 & 2095.96 \\
\hline 2008 & 83537 & 1917 & 84006,8 & 1993.55 \\
\hline 2009 & - & - & 79369.5 & 1918.08 \\
\hline
\end{tabular}

cation, with respect to these criterions of model appropriateness, the use of mentioned method is recommended: Holt's exponential smoothing.

\section{Conclusion}

Accomplishment of fundamental functions and operations of populated regions and cities depends on mass passenger transport that must ensure all necessary transport requirements. To forefront extends distinctively strongly urgency of good coordination of all operations in complete transport systems and in conditions of
Table 7 increasing transport requirements and demands there is a need of development of regions and cities. [4]

The self-contained participants are essential in the process coordination (municipalities, cities, interest groups, natural person, juristic person, etc.) and put the emphasis on creativity, communication ability, ideas richness, engagement, effort to solve problems, flexibility, persuasion and natural authority. [1]

In regional management it is necessary to create a modern and elementary procedure and structure of managerial work. Just implementation of appropriate prognostic methods and planning models those allows to determine the planned value of supply and demand by evaluation of time series trend introducing the possible solution to reach stable and long time results of region and transport enterprise activities and also the application of intelligent transport systems, integrating transport systems, safety and quality of services.

Regional management of the area can allow to Slovak regions and municipalities fast adaptation to conditions of EU market as innovation and integrated management tools. Regional management can help to break through and assume to market with competitive supply gives to Slovaks new human and financial capital and so ensures a long-term perspective and permanent sustainable development. [1]

\section{Acknowledgement}

This contribution is the result of the project implementation: Centre of excellence for systems and services of intelligent transport, ITMS 26220120028 supported by the Research \& Development Operational Programme funded by the ERDF.

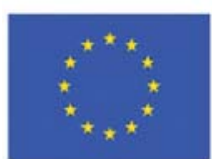

Európska únia

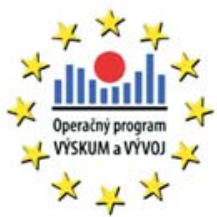

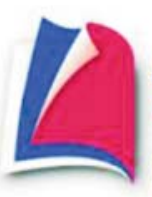

Agentúra

Ministerstva školstva, vedy, výskumu a športu SR pre štrukturálne fondy EÚ

"Podporujeme vyskumne aktivity na Slovensku/Projekt je spolufinancovany zo zdrojov EU."

\section{References}

[1] DICOVA, J.: Importance of Regional Planning and Regional Management for Regions Development (in Slovak). In: Ref. of Intern. seminar Regionalni management a E-learning, Pardubice: Fakulta ekonomicko-spravni : Univerzita Pardubice, 2006, pp. 19-23, ISBN 80-7194-917-5.

[2] CHAJDIAK, J., RUBLIKOVA, E., GUDABA, M.: Statistic Methods in Practice (in Slovak), STATIS Bratislava, 1994.

[3] POLIAK, M., KONECNY, V.: Market of Mass Public Transport and its Financing (in Slovak), Zilinska univerzita, 2009, ISBN 97880-8070-999-0

[4] SUROVEC, P.: Mass Public Transport (in Slovak), Zilinska univerzita, 2007, ISBN 978-80-8070-686-9.

[5] SUROVEC, P.: Technology of Mass Public Transport (in Slovak), Zilinska univerzita, 1998, ISBN 80-7100-494-4.

[6] Government Resolution of SR Nr. 377/2005 Conception of public buss and railway transport with emphasis on systemic solution of financing performances in public interests in 2005 and following years.

[7] The Statistical Office of the Slovak Republic - www.statistics.sk. 